\title{
Future Hydrologic Extremes of the Red River Basin
}

\author{
DARRIAN BERTRAND \\ Department of Geography and Environmental Sustainability, University of Oklahoma, Norman, Oklahoma \\ RENEE A. MCPHERSON \\ Department of Geography and Environmental Sustainability, University of Oklahoma, \\ and South Central Climate Adaptation Science Center, Norman, Oklahoma
}

(Manuscript received 12 December 2017, in final form 24 March 2018)

\begin{abstract}
Hydrologic extremes of drought and flooding stress water resources and damage communities in the Red River basin, located in the south-central United States. For example, the summer of 2011 was the third driest summer in Oklahoma state history and the driest in Texas state history. When the long-term drought conditions ended in the spring of 2015 as El Niño brought record precipitation to the region, there were also catastrophic floods that caused loss of life and property. Hydrologic extremes such as these have occurred throughout the historical record, but decision-makers need to know how the frequency of these events is expected to vary in a changing climate so that they can mitigate these impacts and losses. Therefore, the goals of this study focus on how these hydrologic extremes impact water resources in the Red River basin, how the frequency of such events is expected to change in the future, and how this study can aid local water-resource managers and decision-makers. Heavy-precipitation events were defined at the historical 90th and 99th percentiles, and severe-drought events were identified at a threshold of the standardized precipitation evapotranspiration index's value of less than or equal to -1 . The results show an increase in the frequency of severe-drought events in the western Red River basin and a rise in heavy-rainfall events in the east by the end of the century, especially under RCP 8.5. Therefore, decision-makers and water-resource managers will likely need to prepare for both hydrologic extremes depending on their location within the basin.
\end{abstract}

\section{Introduction}

Hydrologic extremes of heavy precipitation and severe drought stress water resources and damage communities in the Red River basin, located in the south-central United States. For example, the summer of 2011 was the third driest summer in Oklahoma state history and the driest in Texas history since records began in 1895. These states suffered great losses from prolonged drought conditions, with U.S. Drought Monitor category D4 (exceptional drought) applying to almost all of Texas and nearly $70 \%$ of Oklahoma by area. As the long-term drought conditions finally ended in the spring of 2015, El Niño brought record amounts of precipitation to the region, resulting in catastrophic floods that caused loss of life and property. For example, daily rainfall values on 18 June 2015 included $2 \mathrm{in}$. $(1 \mathrm{in} .=2.54 \mathrm{~cm})$ in Durant, Oklahoma, and as much as

Corresponding author: Darrian Bertrand, dmbertra@ncsu.edu
10.5 in. in Newport, Oklahoma (Oklahoma Climatological Survey 2015).

Hydrological extremes, hereby defined as heavy-rainfall and severe-drought events, have occurred throughout the historical record and are expected to continue in the future, but decision-makers need to know if and how the frequency of these events may vary in a changing climate so that they can mitigate these losses. Therefore, this research has examined how these hydrologic extremes affect water resources in the Red River basin, how the frequency of such events is expected to change in the future, and how this study can aid local water-resource managers and decision-makers.

To analyze the future frequency of hydrological extremes, this study used statistically downscaled climate projections, which use quantifiable relationships between large-scale climate variables, or predictors, and small-scale surface variables, or predictands (Wilby et al. 2004). Downscaling generates high-resolution, detailed output that is more useful to decision-makers 


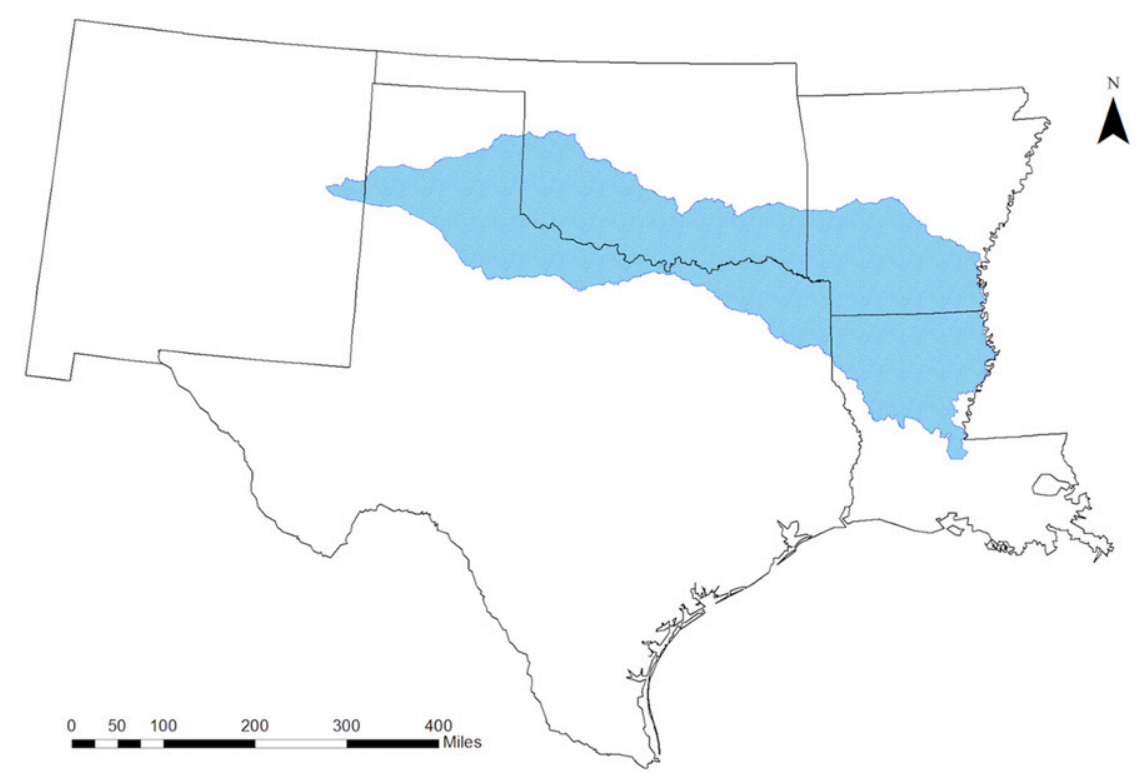

FIG. 1. Red River basin (Bertrand and McPherson 2018, manuscript submitted to Climate Serv.).

and local resource managers than coarse-resolution global climate models (GCMs; Maurer et al. 2014; Thrasher et al. 2013) are. GCMs are numerical models that simulate Earth's large-scale atmospheric and oceanic processes and take greenhouse-gas concentrations into account (IPCC 2013). GCMs calculate the evolution of climate variables, such as temperature and precipitation, that quantitatively describe future climatic changes, but they currently only provide output in a coarse resolution of generally several hundreds of kilometers (Wilby et al. 2004; IPCC 2013, UCAR 2011; Prudhomme et al. 2002). In addition, GCMs have limitations, including biases in climate forcings of greenhouse gases, natural variability, and rainfall (Eden et al. 2012; Schmidli et al. 2006). Downscaling is typically used to correct for these biases and to gain local-scale information that is more beneficial for impact assessments and for decision-makers and water-resource managers.

\section{Study area}

The Red River basin has a diverse climate, with average yearly rainfall totals ranging from approximately 500 to $1300 \mathrm{~mm}(20-50$ in.) from the west to the east, respectively. The basin, covering $239361 \mathrm{~km}^{2}$, spans from New Mexico to the Mississippi River (Fig. 1; Bertrand and McPherson 2018, manuscript submitted to Climate Serv.) and is important for many ecoregions, the water supply, and cultural and recreational activities (Xue et al. 2016; Bertrand and McPherson 2018, manuscript submitted to Climate Serv.). Conflicts over water resources in the basin have occurred in the past, such as the Supreme Court case Tarrant Regional Water District v. Hermann [133 S. Ct. 2120 (2013); https://www. supremecourt.gov/opinions/12pdf/11-889_5ie6.pdf] that arose after Oklahoma legislatures prohibited out-ofstate water distribution in 2002, preventing Tarrant County, and therefore, Fort Worth, Texas, from continuing to buy water from the state (Malewitz 2013). Another major water rights conflict occurred between the City of Oklahoma City, Oklahoma, and the Choctaw Nation of Oklahoma and Chickasaw Nation from 2011 to 2016, during a time of extreme drought in Oklahoma. These examples shine a light on the issues of water resources in the Red River basin and the local stresses that arise during drought.

On the other end of the spectrum, the Red River basin has experienced heavy and extensive rainfall in the past, resulting in river and flash flooding. For example, record-breaking precipitation amounts in Texas and Oklahoma in May and June of 2015 brought flooding that caused a loss of lives and property (Crouch 2015). Southern Oklahoma's May monthly rainfall was $400 \%$ above average, with over $20 \mathrm{in}$. of rain (Di Liberto 2015). One Oklahoma City station recorded a 1-in-1000-yr rainfall event for an accumulated period of 30 days. In northern Texas, levees broke, leading to flooded homes and voluntary evacuations (Breslin 2015). Although this was a long-lasting event, daily rainfall values reached 2 in. in Durant and 10.5 in. in Newport on 18 June 2015 (Oklahoma Climatological Survey 2015). Periods of flash flooding are a hazard to human health not only 
from high floodwaters, but from raw sewage and other toxic chemicals often contaminating the water supply from the stormwater runoff (Lee 2015; Taylor et al. 2011). Oklahoma and Texas experienced this, with various levels of sewage, oil, and insecticides released into the stormwater. This rainfall event caused at least 31 fatalities (Breslin 2015).

Climate-change studies of the southern plains have discussed a drier and warmer pattern in the future (Gutzler and Robbins 2011; Shafer et al. 2014; Venkataraman et al. 2016). When intermittent heavy-rainfall events occur in this pattern, soils can be too dry to absorb rainfall quickly enough to prevent flooding (Hill et al. 2010). Thus, even during drought conditions, it is important for waterresource managers and decision-makers to understand how flooding is expected to affect their communities. In some cases, increased frequency of these events in the future may make it necessary for water infrastructure to be updated (National Research Council 2011). Given these points, this study identifies whether heavy-rainfall and severe-drought events may be expected to continue in the future for the region.

\section{Methods and data}

\section{a. Research design}

The goal of this study was to identify potential future changes in the frequency of hydrologic extremes in the Red River basin to aid water-resource managers and decision-makers in the region. For our study, hydrologic extremes include heavy-rainfall and severedrought events. Our study applies a dataset of statistically downscaled climate projections for the Red River basin (Bertrand and McPherson 2018, manuscript submitted to Climate Serv.) to determine any future changes in the frequency of these events in our future periods (2046-70 and 2075-99) relative to the historical period (1981-2005). To answer this research question, we first defined a heavy-rainfall and severe-drought threshold for our study area. We then selected a peakover-threshold (POT) approach for both event types to identify the frequency of events that exceeded the thresholds in our selected time frames. Because our goal was to find changes and trends in the future periods, we then computed the 25-yr difference in event frequency between the historical period and each future period across the basin. Our study provides information on a gridcell basis, allowing us to discover spatial patterns that are also useful to decision-makers and communities. The remainder of this section discusses the specific method that we used for our study as well as information about the dataset.

\section{b. Data}

Bertrand and McPherson (2018, manuscript submitted to Climate Serv.) provided details of the dataset, which uses statistical downscaling methods to project a $0.1^{\circ}$ resolution of climate variables, such as minimum and maximum temperature and precipitation on a daily scale. The dataset was created by the Geophysical Fluid Dynamics Laboratory (of the National Oceanic and Atmospheric Administration) and was shared by the South Central Climate Adaptation Science Center (of the U.S. Department of the Interior) to aid decisionmakers and water-resource managers in the basin with local-scale information for long-term water plans (Bertrand and McPherson 2018, manuscript submitted to Climate Serv.). The climate variables were projected for a recent historical period of 1961-2005 and through the end of the twenty-first century, or 2006-99, for various representative concentration pathway (RCP) scenarios.

After an evaluation of GCMs from phase 5 of the Coupled Model Intercomparison Project (CMIP5; Taylor et al. 2012), three models were selected to be downscaled: the Community Climate System Model (CCSM4; Gent et al. 2011), the Model for Interdisciplinary Research on Climate, version 5 (MIROC5; Watanabe et al. 2010), and the Max Planck Institute Earth System Model, low resolution (MPI-ESM-LR; Giorgetta et al. 2013). Sheffield et al. (2013) assessed the CMIP5 models on the basis of seasonal temperature and precipitation biases as well as the number of heavy-rainfall days and hot days in several U.S. regions, including central North America, which encompasses our study area (Bertrand and McPherson 2018, manuscript submitted to Climate Serv.). The three GCMs listed above represented the climate of the region well. In addition, relatively smaller climate sensitivities were found in these models (Forster et al. 2013). The dataset includes two quantile-mapping methods that statistically downscaled the data and reduced GCM biases: the cumulative distribution function transform (CDFt; Michelangeli et al. 2009) and equidistant quantile mapping (EDQM; Li et al. 2010) with RCPs of 2.6, 4.5, and 8.5. For more information about the quantile-mapping techniques, model selection, and model evaluation, refer to Bertrand and McPherson (2018, manuscript submitted to Climate Serv.).

For our comparative analysis, 25-yr time periods were chosen from the dataset, which include a historical period of 1981-2005 and two future periods of 2046-70 and 2075-99 to offer a midcentury and end-of-century analysis. In addition, RCP scenarios 2.6 and 8.5 were selected to provide a range of possible future radiative forcings. Because our study area lies on a boundary between wet and dry climates, it was important to conduct the analyses for each individual model versus using a multimodel mean. 


\section{c. Heavy-precipitation definition}

The literature has shown that there is no standard definition of an extreme- or heavy-precipitation event, for the term is dependent on the climatological characteristics of the region (Liu et al. 2013; Schoof and Robeson 2016). For example, in a dry location where it is typical to have little precipitation, the threshold of heavy rainfall is different from that in an area prone to convective storms with heavy downpours. Although there is a lack of clarity in heavy-rainfall definitions, there are various criteria of these events in the literature for different study areas. Some researchers use a specific daily rainfall value that is set as the threshold. For example, a study in India defined a "heavy [rainfall] event" as $100 \mathrm{~mm}$ day $^{-1}$ of precipitation and a "very heavy event" as $150 \mathrm{~mm}$ day $^{-1}$ (Goswami et al. 2006). In addition, Vavrus et al. (2015) classified a heavy-precipitation event in the northeastern United States as having at least $2 \mathrm{in}$. of rainfall in 1 day.

Return periods and generalized extreme value (GEV) distributions have also been used to study extreme rainfall. For example, results from Kharin et al. (2013) revealed that the historical 20 -yr return period is reduced to as much as 6 years in the future for CMIP5 models. Cheng and AghaKouchak (2014) assess intensityduration curves with GEV distributions to compute several return periods under stationary and nonstationary climates, revealing more extremes in a nonstationary environment. Furthermore, Tryhorn and DeGaetano (2011) developed GEV distributions to validate their statistical downscaling techniques by analyzing extremeprecipitation events in the northeastern United States. They found that the simulated return periods were within the $95 \%$ confidence interval of the observations and the GEV distributions.

On the other hand, many studies utilize a percentile approach. Zhang et al. (2011) state that using percentile thresholds and the number of days exceeding those thresholds allows us to compare frequencies spatially. This method is also termed a POT approach, which Villarini et al. (2013) similarly use to assess precipitation values at the 95th percentile. Schoof and Robeson (2016) list indicators created by the Expert Team on Climate Change Detection and Indices (ETCCDI) from the World Meteorological Organization Commission for Climatology (CCI)/World Climate Research Programme's Climate and Ocean: Variability, Predictability and Change (CLIVAR) project (Vavrus et al. 2015) in which "extremely wet days" are calculated by the 99th percentile of annual total precipitation.

Another instance of a 99th-percentile method is shown in Emori and Brown (2005), in which they use this threshold with daily precipitation from six climate models.
Other percentile values have been found in the literature as well, such as that of Zhai et al. (2005) that determines the frequency of extreme-rainfall events over time in China, which are classified as days with rainfall greater than the 95th percentile for a selected period. Therefore, implementing a POT approach from a set percentile is commonly found in the literature and is implemented in this study to analyze the frequency of heavy-precipitation events occurring from a spatial perspective.

In our study, we selected the POT approach with thresholds of the 90th and 99th percentiles of rain days in the 25-yr historical period of 1981-2005, on the basis of the statistically downscaled dataset used in this study. The percentiles of the historical period and the number of daily events exceeding each of these thresholds in the historical and future periods (2046-70 and 2075-99) were calculated across the Red River basin through the $\mathrm{R}$ software package, version 3.3.2 (https://www.R-project.org/). From here on, the number of events that exceed the 90th and 99th percentiles of the historical period are referred to as the "frequency of heavy-precipitation events," and the future events at these thresholds are denoted as "90th-" and "99th-percentile events." The differences, or changes, between the historical frequency and each future frequency across the basin were then computed to determine whether there were any increasing or decreasing trends in heavy-precipitation events. Our computed values thus represent the change in the number of days during a 25-yr period and not yearly differences.

\section{d. Severe-drought definition}

The second type of hydrologic extreme analyzed in this study is drought. Drought also has many definitions, depending on the application, and there are various kinds of drought, such as meteorological, agricultural, and hydrological (Palmer 1965). For the purpose of finding short-term hydrologic extremes, this study focused on meteorological drought. Even focusing on this one kind of drought, much of the literature highlights that there is not a standard way to define or measure the hazard (Dracup et al. 1980; Wilhite and Glantz 1985; Wilhite 2000). A concise definition by the National Weather Service is, "a deficiency of moisture that results in adverse impacts on people, animals, or vegetation over a sizeable area" (NOAA 2016).

One method to measure drought empirically is through drought indices, such as the standardized precipitation index (SPI; McKee et al. 1993). The SPI is user friendly, allowing the user to calculate the drought conditions for specific time frames and determine how many droughts, and at what magnitude, have occurred in that time frame (McKee et al. 1993; Guttman 1998; Keyantash and Dracup 2002). This index can be computed by creating probability distribution functions for 
the long-term precipitation of a location for a selected time scale and then calculating the cumulative probability of a certain precipitation amount (McKee et al. 1993; Guttman 1999). The SPI value is then estimated by applying an inverse normal function to the probabilities with a mean of 0 and standard deviation of 1 . Therefore, the SPI provides the probability of a wet or dry event occurring by showing the number of standard deviations by which the values deviate from the mean. Negative SPI values represent a deficiency in moisture relative to local normal climate, and positive values are above the median precipitation (Guttman 1999).

The SPI does not take evapotranspiration into consideration, and thus it is unfortunately insufficient to use in a warming world. Instead, the standardized precipitation evapotranspiration index (SPEI) accounts for the SPI's limitations and provides the ability to perform a multiscalar analysis (Vicente-Serrano et al. 2010b). The SPEI can be calculated with

$$
\text { SPEI }=P-\text { PET, }
$$

where $P$ is monthly total precipitation and PET is the potential evapotranspiration (Vicente-Serrano et al. 2010b). There is an R package ("SPEI") for simple calculation of the drought index at various time scales (Beguería and Vicente-Serrano 2013). Through this software package, users can choose different methods for the calculation of PET. Examples include the Thornthwaite equation (Thornthwaite 1948) that uses mean daily temperature and latitude and the Hargreaves equation (Hargreaves and Samani 1985) that uses monthly average minimum and maximum temperature. The latter is given by

$$
\mathrm{ET}_{0}=0.0023 R_{a}(\mathrm{TC}+17.8) \mathrm{TR}^{0.5},
$$

where $\mathrm{ET}_{0}$ is reference evapotranspiration, $R_{a}$ is the radiation component, TC is the mean temperature in degrees Celsius for the time period, and TR is the daily temperature range (Hargreaves and Samani 1985). The Thornthwaite and Hargreaves equations require different data variables for calculation of PET but do not have specific requirements for the number of observations.

Venkataraman et al. (2016) used this package to calculate the SPEI in Texas under three emission scenarios through the end of the twenty-first century. They chose to calculate PET, and thus the SPEI, with the Hargreaves method because other research has shown that the Thornthwaite equation is not ideal for climate-change studies because the method overestimates drought conditions with increased temperatures (Lockwood 1999). Amatya et al. (1995) analyzed several methods of calculating PET, including Thornthwaite and Hargreaves, and found that the Thornthwaite method performed worst for their humid study area of North Carolina. Furthermore, Lu et al. (2005) discovered that PET values calculated from the Thornthwaite equation were the lowest among six methods used to calculate PET in the southeastern United States, including a watershed in Arkansas.

For our study, the SPEI was the most suitable drought index because it could easily be calculated from limited climatological variables, such as monthly minimum and maximum temperature and monthly precipitation (VicenteSerrano and National Center for Atmosperic Research Staff 2015), as recommended by Beguería et al. (2014). The SPEI R package also allows the user to input the time scale desired for the calculation, which is important for multiscalar analyses whereby drought is examined at different time scales, such as for long-term assessments and impacts.

The variables of daily minimum and maximum temperature and daily precipitation in our downscaled dataset enabled a simple calculation of PET using the Hargreaves method and then further computation of SPEI. To run the package in $\mathrm{R}$, monthly average minimum and maximum temperatures and monthly total precipitation were required for both the historical and future time periods. We then calculated PET and SPEI values for each grid cell in the Red River basin at a 1-month time scale from these monthly averages and totals to assess short-term drought, and then we computed the frequency of severe-drought events for each grid cell in the basin.

The SPEI classifies extreme drought as a value of less than or equal to -2 (McKee et al. 1993). Our study discovered that these events are rare, especially during $25-\mathrm{yr}$ periods; hence, we selected a threshold of SPEI of less than or equal to -1.5 to encompass severe drought. Our study's historical period of 1981-2005 was a wetter period than other 25-yr periods on record (Fig. 2), and it did not contain the high-magnitude drought of the 1950s or 1960s, thus clarifying the small number of extremedrought events and length of drought found. Similar to the heavy-precipitation analysis, the differences between the historical frequency and each future frequency across the grid were calculated to determine any changes in severe drought through the twenty-first century.

\section{Results}

\section{a. Heavy precipitation}

The difference between the number of heavy-precipitation events in the historical period (1981-2005) and each future period (2046-70 and 2075-99) was calculated for the ensemble that used CCSM4, MIROC5, and MPIESM-LR models with CDFt and EDQM downscaling techniques for RCP 2.6 and RCP 8.5 across the Red 


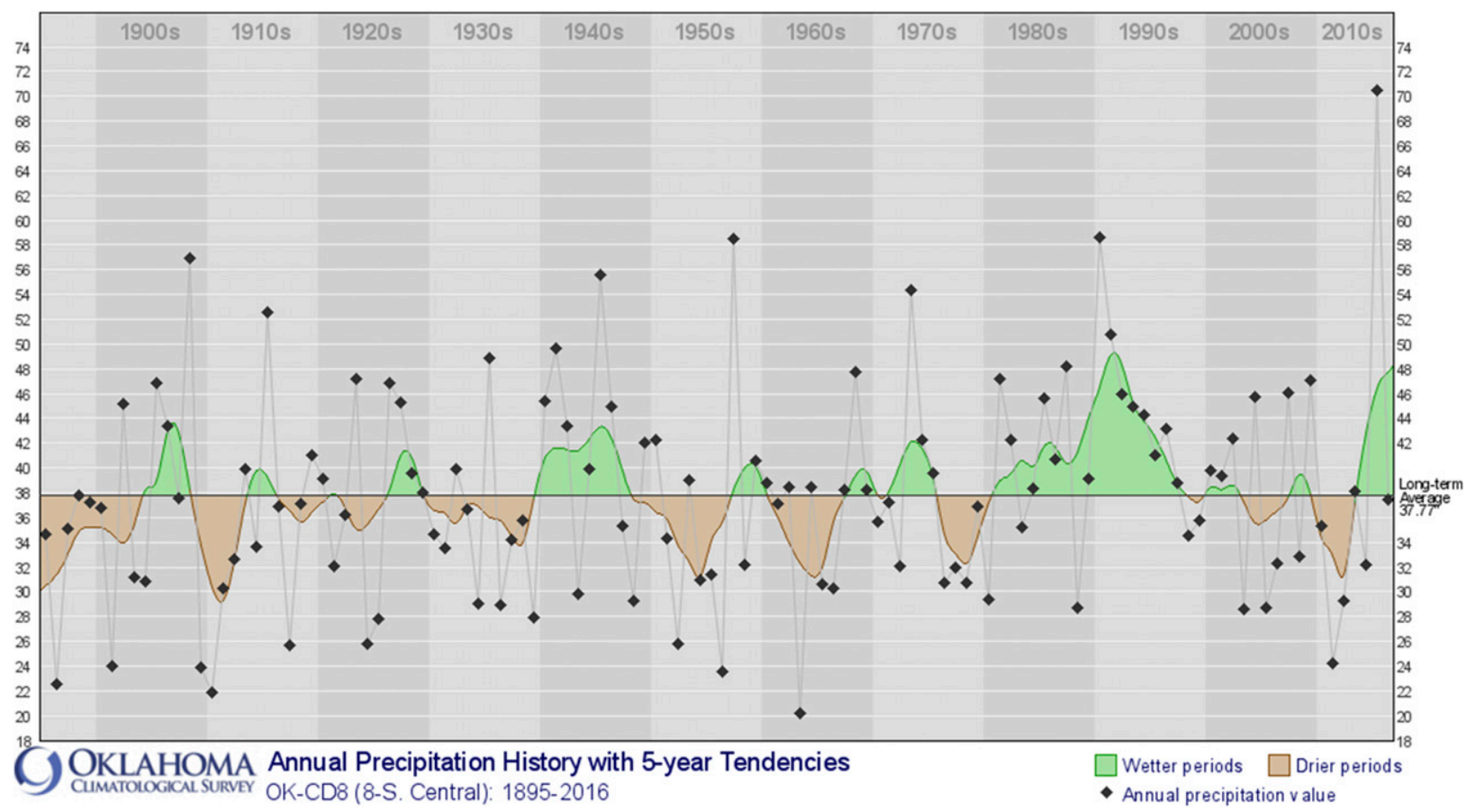

FIG. 2. Long-term annual precipitation history for the south-central climate division in Oklahoma (Oklahoma Climatological Survey 2017).

River basin. The 90th percentile of precipitation during the historical period ranged from approximately 7 to $35 \mathrm{~mm}(0.3-1.4 \mathrm{in}$.) per day across the basin, and the 99th percentile spanned from 22 to $88 \mathrm{~mm}(0.9-3.5 \mathrm{in}$.) per day. Heavy-precipitation thresholds increased to the east, coinciding with the average annual precipitation gradient of approximately $500-1300 \mathrm{~mm}$ (20-50 in.) per year (USGS 2017; Bertrand and McPherson 2018, manuscript submitted to Climate Serv.).

For example, the threshold for the grid cell that encompassed Amarillo, Texas, which is located in the Texas Panhandle, in the CCSM4 model was $12.3 \mathrm{~mm}$ (0.5 in.) for the historical 90th percentile and $32 \mathrm{~mm}$ (1.3 in.) for the 99th percentile. In the center of the basin, the heavy-precipitation threshold near Ardmore, Oklahoma, was $17.6 \mathrm{~mm}(0.7 \mathrm{in}$.) for the 90th percentile and $42.6 \mathrm{~mm}$ (1.7 in.) for the $99 \mathrm{th}$ percentile. Eastern locations exhibited higher thresholds, such as a 90th percentile of $17.6 \mathrm{~mm}(0.7 \mathrm{in}$.) and a 99th percentile of $52.2 \mathrm{~mm}(2.1 \mathrm{in}$.) in the grid cell that contains Shreveport, Louisiana. Because the thresholds were calculated from rain days, the annual number, or frequency, of 90th- and 99th-percentile events in the historical period was dependent on location and followed the west-to-east gradient as well, as seen in Fig. 3. Note that gridded data produce a lower frequency of heavy-rainfall events, because the grid cell is averaging what would be several point observations (Ensor and Robeson 2008; Contractor et al. 2015).
The future projected change in the amount of precipitation associated with the historical 90th-percentile threshold varies among models, statistical downscaling techniques, and RCP scenarios and is shown in Table 1, where negative values are associated with decreasing events and positive values show increasing events. Overall, we discovered a decreasing trend of events that exceed the historical 90th-percentile thresholds in the west and an increase in these events in the east for the future scenarios. These trends were not consistent across all models and all RCP scenarios. For example, the midcentury (2046-70) results for RCP 2.6 included an increase in heavy-precipitation events across much of the basin for the MIROC5 model but a basinwide decrease in events for the CCSM4 model (Fig. 4). In addition, the CCSM4 midcentury results for RCP 8.5 included a basinwide decrease in 90th-percentile days, and results for MIROC5 were variable on each run.

The largest decreases in extreme-precipitation events at the 90th percentile occurred in the RCP scenario 8.5, especially for the end-of-century period. For example, projections from the MPI-ESM-LR model and CDFt downscaling technique estimated locations in the far western portion of the basin to have a decrease in the number of 90th-percentile daily events by as many as 249 days as compared with the approximately 900 events that occurred in the historical 25-yr period (Table 1, top half; Fig. 5). The EDQM technique demonstrated the 

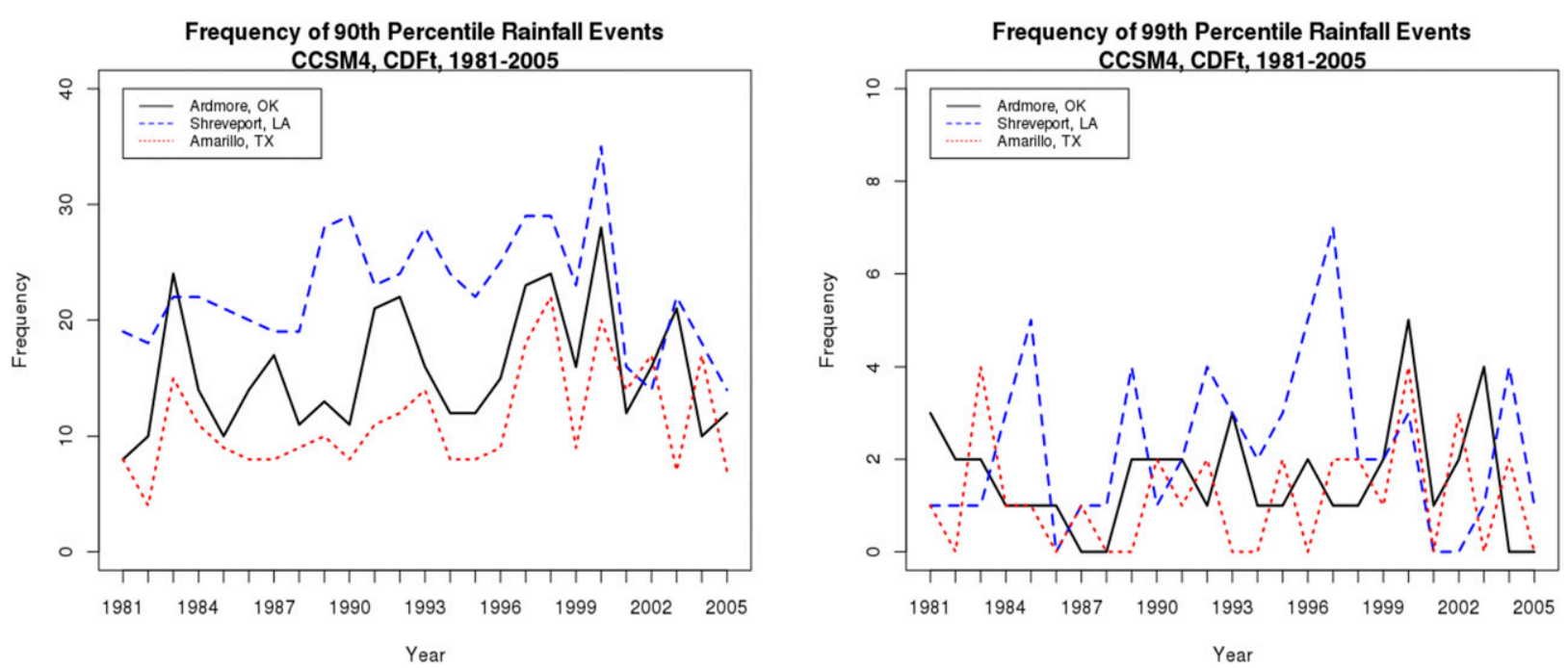

FIG. 3. Annual occurrence of 90th- and 99th-percentile events in the historical period for three locations in the Red River basin. The red line represents results for Amarillo, the black line represents Ardmore, and the blue line represents Shreveport.

same pattern; the change in number of events was not as large as for the CDFt results, however, with the greatest decrease being 98 days in this scenario and time frame. There were projected increases in heavyrainfall events as well, most noticeably in the MPIESM-LR model. This model estimated some locations in the east to have approximately 113 more 90th-percentile rainfall days by the end of the century under the RCP scenario 8.5 for both downscaling techniques as compared with the 900 events that occurred in the historical period.

Results for rainfall events associated with the 99th percentile of the historical period showed patterns that are similar to those of the 90th percentile, with the most common pattern being an increase in heavy-rainfall days in the east and many fewer occurring in the west. There were model differences in trends relative to the 90thpercentile events, however. For example, whereas the MPI-ESM-LR model exhibited the highest decrease in extreme events in the basin for the 90th percentile, the MIROC5 (during the end-of-century period for RCP 8.5) and the CCSM4 portrayed this characteristic in the 99th percentile for both the CDFt and EDQM techniques (Figs. 6 and 7). All three models projected a decrease in mean daily precipitation in the western Red River basin (Bertrand and McPherson 2018, manuscript submitted to Climate Serv.), but the models were handling extremes differently.

TABLE 1. Minimum and maximum number of days for the change in the 25-yr period of heavy-precipitation events at the 90th and 99th percentile of the historical period versus the future. Change in the number of days is calculated under RCP scenarios 2.6 and 8.5 (columns) for each model and statistical downscaling technique (SD), and the range across the basin is displayed as the basin minimum (left side of slash) and maximum (right side of slash).

\begin{tabular}{|c|c|c|c|c|c|}
\hline \multirow[b]{2}{*}{ Model, SD } & \multicolumn{2}{|c|}{ Midcentury (2046-70) } & \multicolumn{2}{|c|}{ End of century (2075-99) } & \multirow{2}{*}{$\frac{\text { Historical (1981-2005) }}{\mathrm{Min} / \max }$} \\
\hline & $\mathrm{RCP} 2.6 \mathrm{~min} / \mathrm{max}$ & $\mathrm{RCP} 8.5 \mathrm{~min} / \mathrm{max}$ & $\mathrm{RCP} 2.6 \mathrm{~min} / \mathrm{max}$ & $\mathrm{RCP} 8.5 \mathrm{~min} / \mathrm{max}$ & \\
\hline \multicolumn{6}{|l|}{ 90th percentile } \\
\hline CCSM4, CDFt & $-76 / 47$ & -1234 & -10847 & $-84 / 74$ & $0 / 691$ \\
\hline MIROC5, CDFt & $-23 / 105$ & $-71 / 92$ & $-37 / 111$ & $-133 / 27$ & $0 / 627$ \\
\hline MPI-ESM-LR, CDFt & $-112 / 57$ & $-185 / 71$ & $-112 / 112$ & $-247 / 76$ & $0 / 913$ \\
\hline CCSM4, EDQM & $-70 / 59$ & $-104 / 13$ & $-90 / 59$ & $-75 / 59$ & $0 / 499$ \\
\hline MIROC5, EDQM & $-27 / 92$ & $-82 / 66$ & $-48 / 116$ & $-119 / 12$ & $0 / 499$ \\
\hline MPI-ESM-LR, EDQM & $-61 / 68$ & $-8 / 597$ & $-49 / 101$ & $-98 / 113$ & $0 / 419$ \\
\hline \multicolumn{6}{|l|}{ 99th percentile } \\
\hline CCSM4, CDFt & $-24 / 68$ & $-24 / 65$ & $-29 / 40$ & $-23 / 72$ & $0 / 70$ \\
\hline MIROC5, CDFt & $-18 / 45$ & $-21 / 51$ & $-21 / 45$ & $-12 / 51$ & $0 / 63$ \\
\hline MPI-ESM-LR, CDFt & $-24 / 44$ & $-23 / 53$ & $-23 / 53$ & $-14 / 71$ & $0 / 92$ \\
\hline CCSM4, EDQM & $-22 / 34$ & $-19 / 34$ & $-24 / 15$ & $-20 / 32$ & $0 / 50$ \\
\hline MIROC5, EDQM & $-12 / 43$ & $-9 / 45$ & $-15 / 46$ & $-9 / 68$ & $0 / 50$ \\
\hline MPI-ESM-LR, EDQM & $-10 / 30$ & $-16 / 35$ & $-16 / 35$ & $-11 / 49$ & $0 / 42$ \\
\hline
\end{tabular}


(a) Model: CCSM4, SD: CDFt

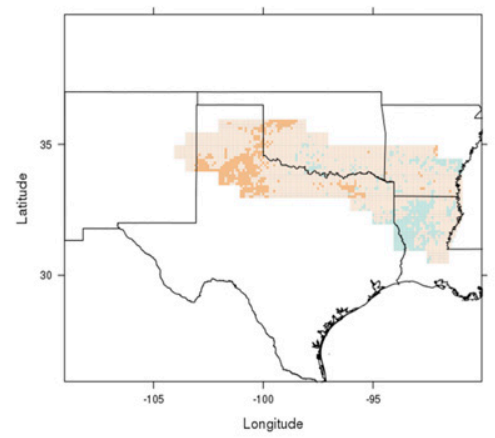

(d) Model: CCSM4, SD: EDQM

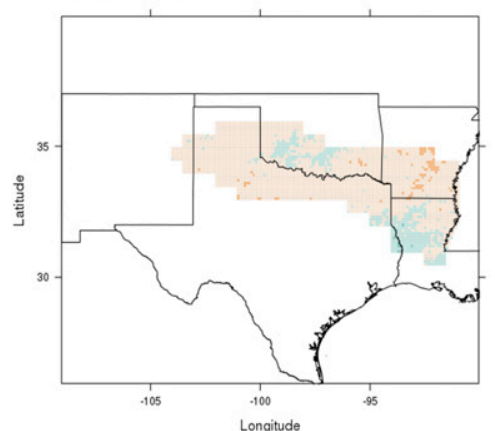

(b) Model: MIROC5, SD: CDFt

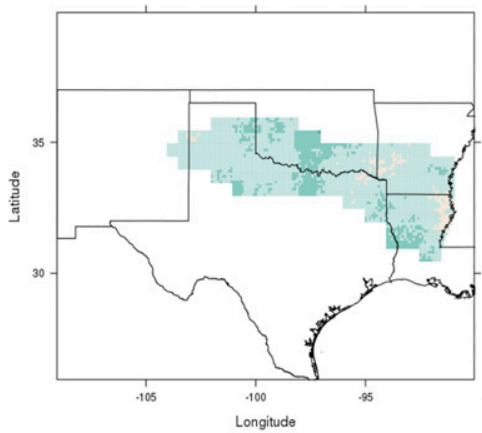

(e) Model: MIROC5, SD: EDQM

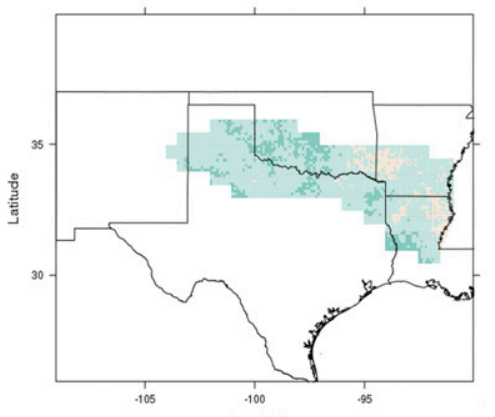

(c) Model: MPI-ESM-LR, SD: CDFt

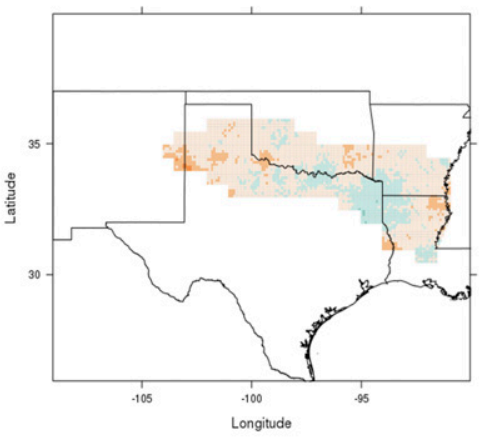

(f) Model: MPI-ESM-LR, SD: EDQM

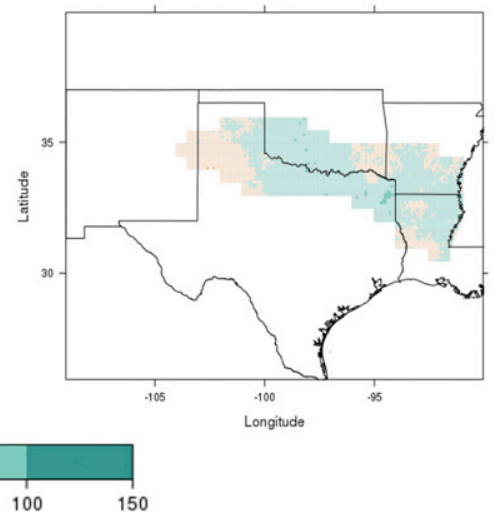

FIG. 4. Change in 25-yr total frequency of all heavy-rainfall days over 25 years at the 90th percentile between the historical period (19812005) and midcentury period (2046-70) under RCP scenario 2.6. Orange shades represent a decrease in events, and green shades represent an increase.

When we compared results for the midcentury period under RCP 2.6 (Fig. 6) versus the end-of-century period under RCP 8.5 (Fig. 7), we noticed that heavy-rainfall events are affected by different emission scenarios and time frames as well. The largest decreases in events occurred in the 2075-99 time frame for the CCSM4 model for which the western and central portions of the basin were estimated to experience up to nearly 30 fewer heavy-rainfall days as compared with the 70 events that the CCSM4 modeled for the historical period (Table 1, bottom half).

Increases in 99th-percentile events were variable and dependent on the model and RCP scenario. Most model runs projected an increase in heavy-precipitation events in the eastern Red River basin. These results agree with Wuebbles et al. (2014) who used CMIP5 models to indicate that rainfall in the United States is projected to increasingly fall in the 99th percentile of their long-term historical period, especially in RCP scenario 8.5. The most widespread increases in the end-of-century period occurred using the MPI-ESM-LR model, especially in RCP scenario 8.5, which includes approximately 70 more heavy-rainfall days than the historical period. The difference is a sizeable change and indicates that the number of heavy-precipitation events may increase by more than $75 \%$ in this area when compared with the historical period.

Sillmann et al. (2013) analyzed the performance of the CMIP5 models for extreme indices and stated that the MPI-ESM-LR model produces the greatest simple daily intensity, an extremes index from ETCCDI, in millimeters per day versus other models, which could explain a higher number of events occurring with this model. Dosio (2016) found that the MPI-ESM-LR model overestimates precipitation. This overestimation also occurred in the mean daily precipitation analysis of the Red River basin in comparison with observational data (Bertrand and McPherson 2018, manuscript submitted to Climate Serv.). There were differences between models for different time frames and RCP scenarios, but the most common trend included an increase in the number of heavy-rainfall events in the eastern Red River basin, where average annual rainfall is higher, and a decrease in events in the drier, western portions of the basin. 
(a) Model: CCSM4, SD: CDFt

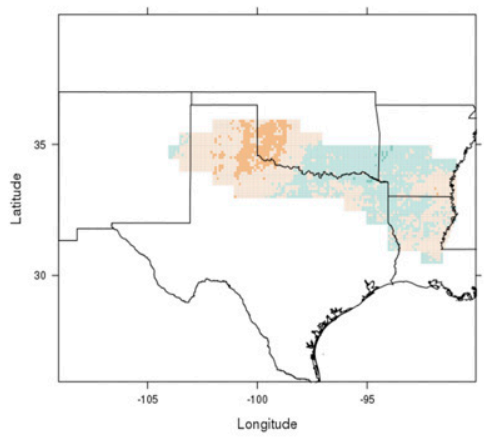

(d) Model: CCSM4, SD: EDQM

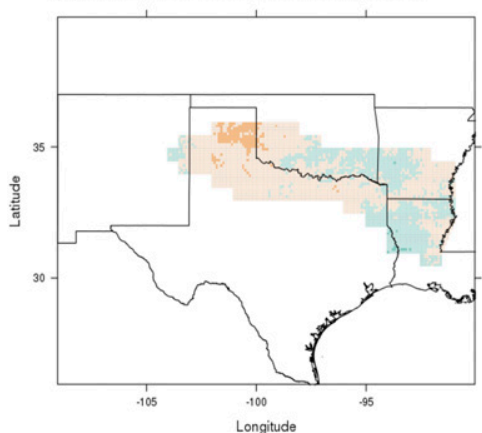

(b) Model: MIROC5, SD: CDFt

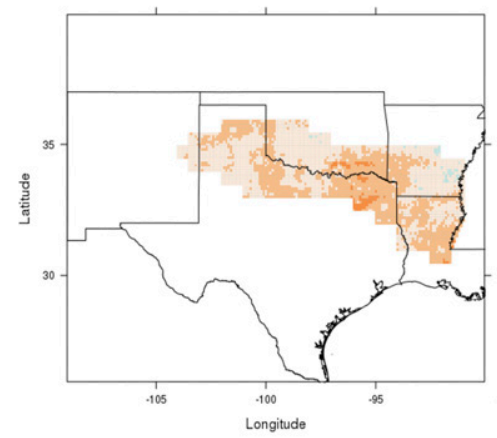

(e) Model: MIROC5, SD: EDQM

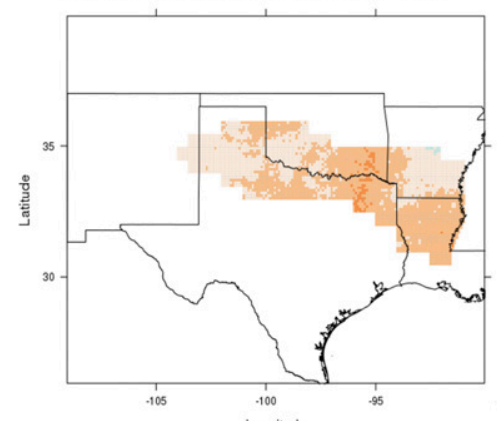

(c) Model: MPI-ESM-LR, SD: CDFt

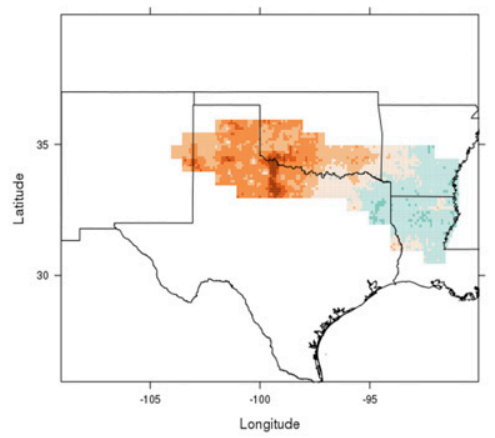

(f) Model: MPI-ESM-LR, SD: EDQM

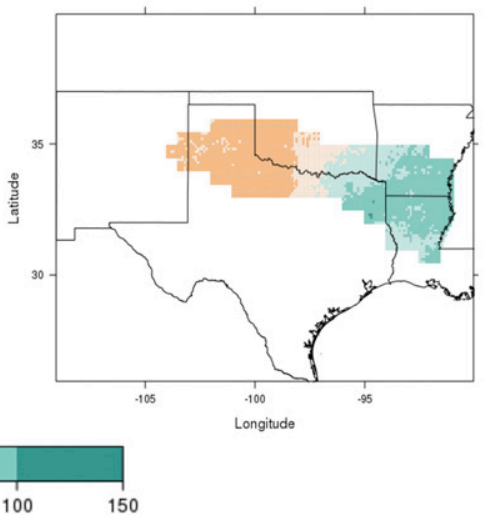

FIG. 5. As in Fig. 4, but between the historical period (1981-2005) and end-of-century period (2075-99) under RCP scenario 8.5.

\section{b. Severe drought}

Similar to the heavy-rainfall analysis, a frequency analysis of severe drought was also computed for each grid cell in the Red River basin for each model, statistical downscaling technique, and RCP scenario for the historical and future time frames. To gauge how meteorological drought may change in the future, we calculated monthly averages of SPEI and counted the number of events for which SPEI was less than or equal to -1.5 . Because the analysis included monthly events, consecutive months of severe drought were considered to be separate events. Drought often occurs for several consecutive months, and so we acknowledge that this could have affected our results. During the 25-yr historical period, the downscaled models indicated that the highest frequency of severe drought in the basin was 24 events, which occurred in southeastern Arkansas and north-central Louisiana (Fig. 8). This result is consistent with NOAA's time series of drought in the southeast climate division of Arkansas (NOAA National Centers for Environmental Information 2017). A similar number of historical severe-drought events were also located in the Texas Panhandle.
Table 2 displays the ranges for the projected change in number of severe-drought events for each future setting, with negative and positive values indicating decreasing or increasing events in the basin, respectively. Overall, the change in severe drought included a range of increasing and decreasing events across the basin. As Table 2 shows, the difference between the number of severe-drought events was relatively consistent from historical to future periods for each model.

Although the minimum and maximum values were similar throughout, there were some spatial trends for each model. For example, the CCSM4 model projected an increase in the number of severe-drought events across northwestern and central portions of the basin and a decline across the southwest and east (Figs. 9 and 10). This pattern was demonstrated in both the midcentury period under RCP 2.6 and the end-of-century period under RCP 8.5; the magnitude of this change was greater for the latter. For example, southwest Oklahoma and north-central Texas may receive up to 12 more severe-drought events between 2075 and 2099 as compared with the historical frequency of 10-15 events over 25 years. Doubling the frequency of these events is likely to cause great damage to communities. Bertrand and McPherson (2018, manuscript 
(a) Model: CCSM4, SD: CDFt

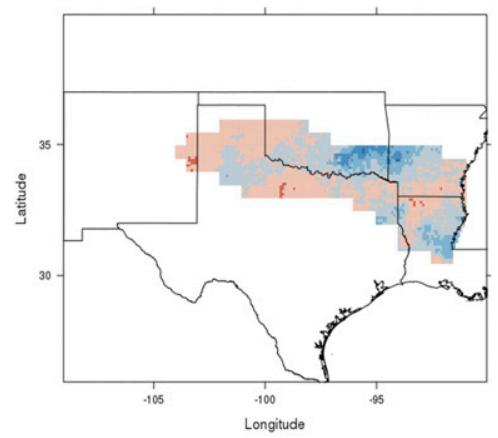

(d) Model: CCSM4, SD: EDQM

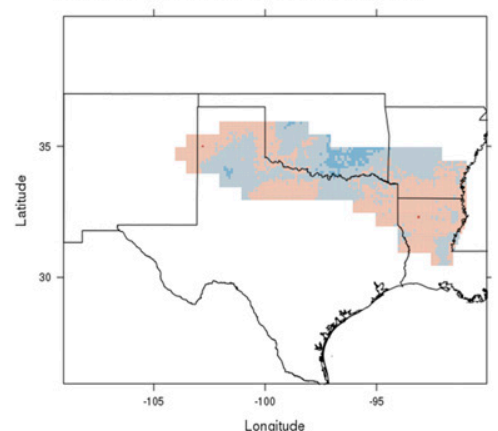

(b) Model: MIROC5, SD: CDFt

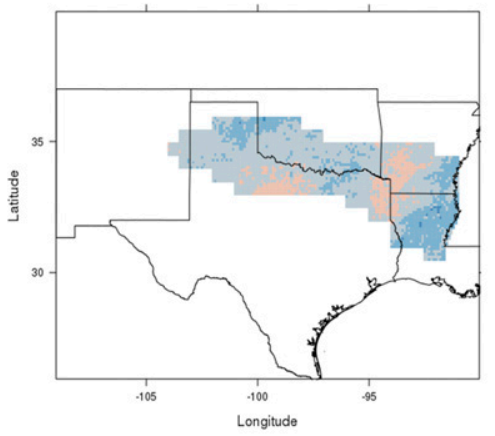

(e) Model: MIROC5, SD: EDQM

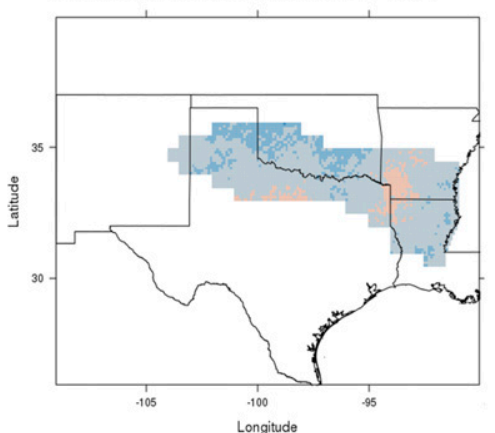

(c) Model: MPI-ESM-LR, SD: CDFt

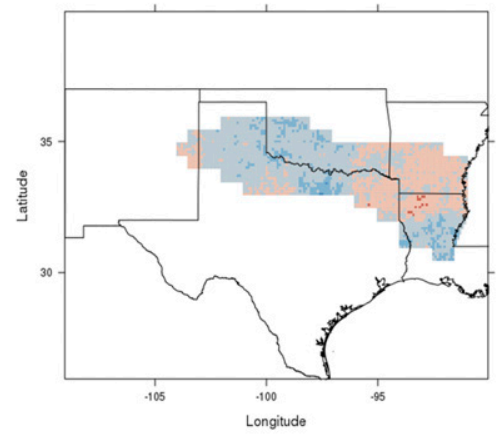

(f) Model: MPI-ESM-LR, SD: EDQM

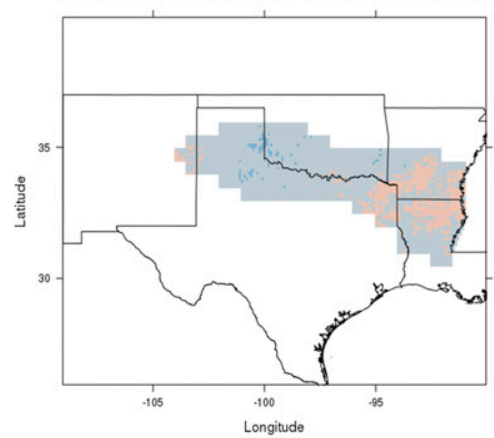

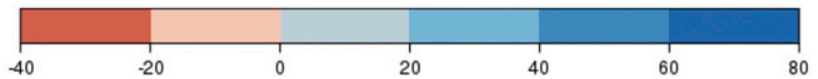

FIG. 6. Change in 25-yr total frequency of all heavy-rainfall days over 25 years at the 99 th percentile between the historical period (19812005) and midcentury period (2046-70) under RCP scenario 2.6. Red shades represent a decrease in events, and blue shades represent an increase.

submitted to Climate Serv.) identified a decrease in mean daily precipitation in the western part of the Red River basin and a rise in both minimum and maximum temperatures, consistent with the projections of more drought events across the west in the future.

The MIROC5 model projected the trend of more severe-drought events in the west and fewer in the east as well. The largest change in these events occurred in the midcentury period under RCP 2.6 for both downscaling techniques, when higher frequencies of severe drought were projected to occur and expand through the central Red River basin. For example, we estimated an increase of at most 14 more events during a 25 -yr period throughout the basin, but especially across southeastern Oklahoma and northeastern Texas, and up to nine fewer events in the east, particularly in southern Arkansas (Table 2, Fig. 9). These results indicate that the frequency of severe drought may double in the western and central areas of the basin; on the other hand, southern Arkansas may experience a decline of these events by one-third in the midcentury period relative to the frequency of historical events.
Our analysis for the end-of-century time frame under RCP 8.5 exhibited the same spatial pattern but had a much weaker signal, indicating a smaller range of severe-drought occurrence than in the historical period (Fig. 10). Under this same RCP scenario for the end-of-century period, there were more widespread areas of decreasing severe-drought events throughout the basin. These results support those of Venkataraman et al. (2016), who computed SPEI values across Texas to assess drought through the twenty-first century. They discovered that locations like Lubbock, located in far-west Texas just south of the Texas Panhandle, are expected to experience more droughts by the end of the century under RCP-8.5 conditions.

Last, the MPI-ESM-LR results included the similar pattern of more severe-drought events in the west and fewer events in the east; the signal was small relative to that of the other two models, and the location of the highest frequency of future events both shifted farther westward and expanded across the southeast (Figs. 9 and 10). This pattern was similar to that of the historical period, as seen in Fig. 8. For example, we estimated an 
(a) Model: CCSM4, SD: CDFt

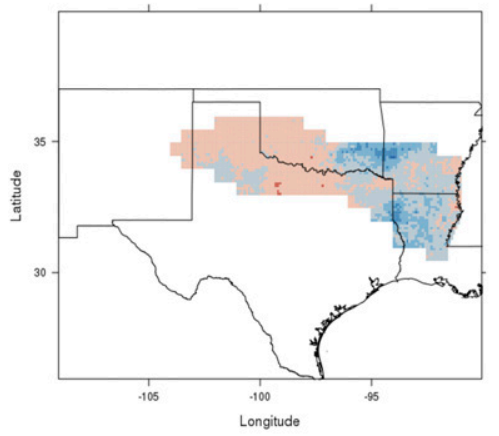

(d) Model: CCSM4, SD: EDQM

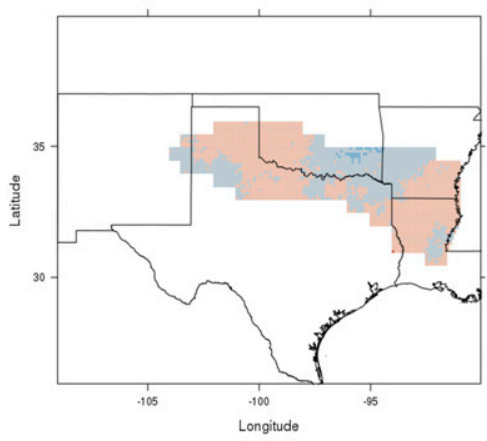

(b) Model: MIROC5, SD: CDFt

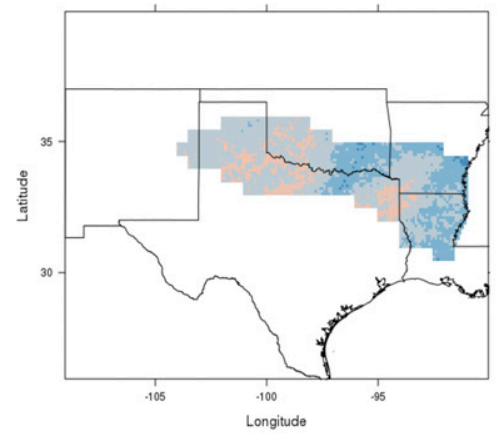

(e) Model: MIROC5, SD: EDQM

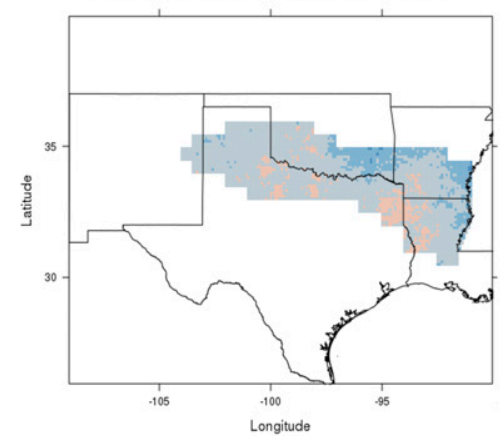

(c) Model: MPI-ESM-LR, SD: CDFt

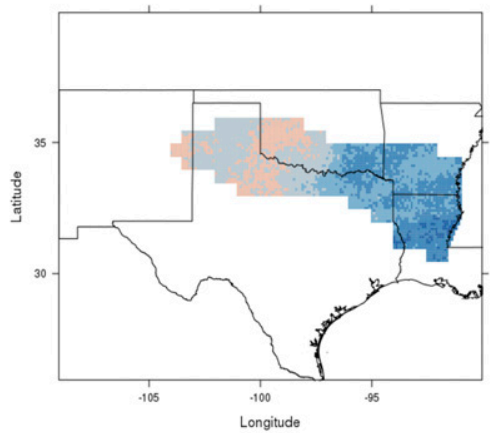

(f) Model: MPI-ESM-LR, SD: EDQM

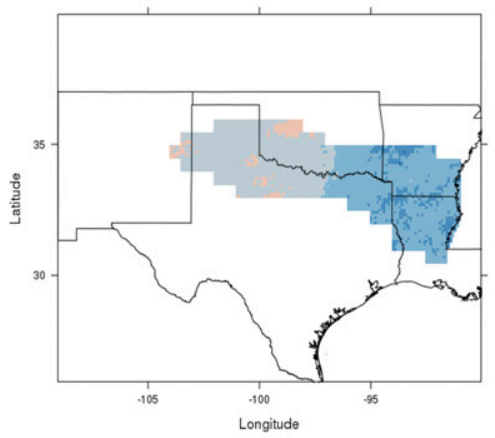

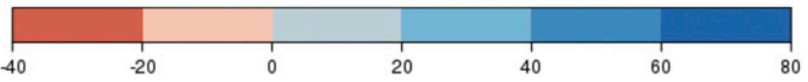

FIG. 7. As in Fig. 6, but between the historical period (1981-2005) and end-of-century period (2075-99) under RCP scenario 8.5.

increase of as many as 12 events near the New Mexico/ Texas border and northeastern Texas during the 25-yr, midcentury period, especially for the EDQM downscaling technique, as compared with the 15-20 events that occurred in the historical period. By the end of the

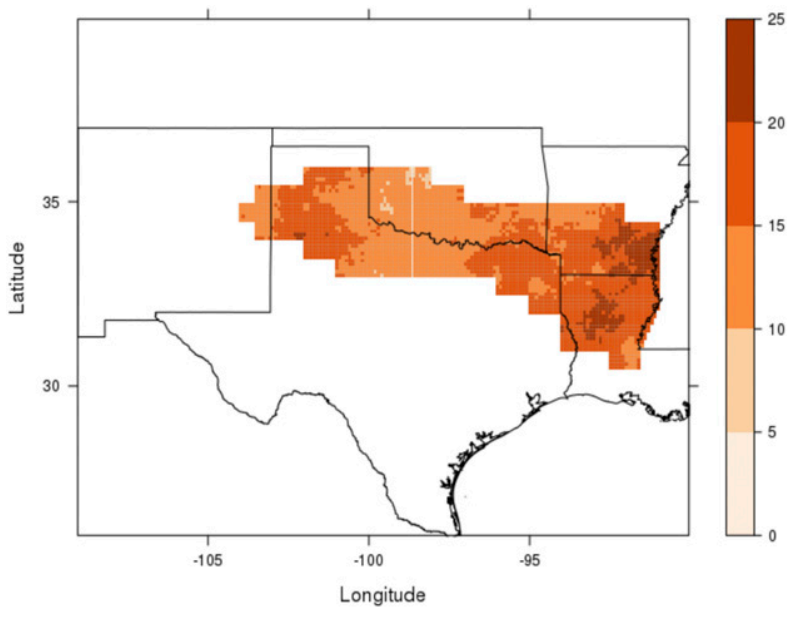

FIG. 8. Spatial representation of the historical drought frequency for the CCSM4 model. century, however, our projections indicate less prominence in the increasing trend of events for the EDQM downscaling technique and a widespread decrease in the number of severe-drought events throughout the basin, with scattered pockets of more events using the CDFt technique (Figs. 10c,f).

Although there is variability among GCMs, we document an overall increase in drought events in portions of the western Red River basin and a decline in the east. Wuebbles et al. (2014) found that CMIP5 models project an increase in the risk of drought in RCP scenario 8.5 in the United States that is due to projected increases in evaporation and decreases in precipitation, which further validates our end-of-century results. Furthermore, with both temperature and precipitation taken into account for the calculation of SPEI, the models were more consistent for our estimation of these events than for our extreme-precipitation analysis.

\section{Conclusions/discussion}

Hydrologic extremes of rainfall and drought have affected the Red River basin in the past, creating negative economic impacts and causing damage to infrastructure 
TABLE 2. Ranges (minimum and maximum) in the change between historical and future frequency of 1-month severe-drought events under RCP scenarios 2.6 and 8.5 for each model and statistical downscaling technique.

\begin{tabular}{|c|c|c|c|c|c|}
\hline \multirow[b]{2}{*}{ Model, SD } & \multicolumn{2}{|c|}{ Midcentury (2046-70) } & \multicolumn{2}{|c|}{ End of century (2075-99) } & \multirow{2}{*}{$\frac{\text { Historical (1981-2005) }}{\mathrm{Min} / \max }$} \\
\hline & $\mathrm{RCP} 2.6 \mathrm{~min} / \mathrm{max}$ & $\mathrm{RCP} 8.5 \mathrm{~min} / \mathrm{max}$ & $\mathrm{RCP} 2.6 \mathrm{~min} / \mathrm{max}$ & $\mathrm{RCP} 8.5 \mathrm{~min} / \mathrm{max}$ & \\
\hline CCSM4, CDFt & $-9 / 8$ & $-12 / 10$ & $-8 / 8$ & $-10 / 12$ & $0 / 24$ \\
\hline MIROC5, CDFt & $-9 / 14$ & $-8 / 13$ & $-8 / 11$ & $-8 / 11$ & $0 / 21$ \\
\hline MPI-ESM-LR, CDFt & $-10 / 10$ & $-6 / 9$ & $-8 / 10$ & $-12 / 8$ & $9 / 21$ \\
\hline CCSM4, EDQM & $-10 / 9$ & $-12 / 8$ & $-11 / 8$ & $-12 / 11$ & $0 / 26$ \\
\hline MIROC5, EDQM & $-13 / 12$ & $-12 / 10$ & $-9 / 7$ & $-12 / 9$ & $0 / 22$ \\
\hline MPI-ESM-LR, EDQM & $-13 / 12$ & $-12 / 10$ & $-9 / 7$ & $-12 / 9$ & $0 / 23$ \\
\hline
\end{tabular}

and water quality and quantity. To alleviate future losses, this study intended to identify the trends in the frequency of future heavy-rainfall and severe-drought events in the basin by using statistically downscaled climate projections through the end of the twenty-first century. By using a peak-over-threshold approach for heavy-rainfall events at the 90th and 99th percentiles of the historical period, we discovered that the selected models generally show an increase in heavy-rainfall events in the eastern portion of the basin and a decrease in the west, especially during the 2075-99 period under RCP scenario 8.5. Results for RCP scenario 2.6, when emissions are reduced, still indicate this trend. Heavy-rainfall events cause large economic impacts from inundated homes and streets, erosion around infrastructure, and reduced water quality. The population in the eastern Red River basin, such as across northeastern Louisiana, may need to prepare for more of these events and their consequences to prevent future damages as well as possible. (a) Model: CCSM4, SD: CDFt

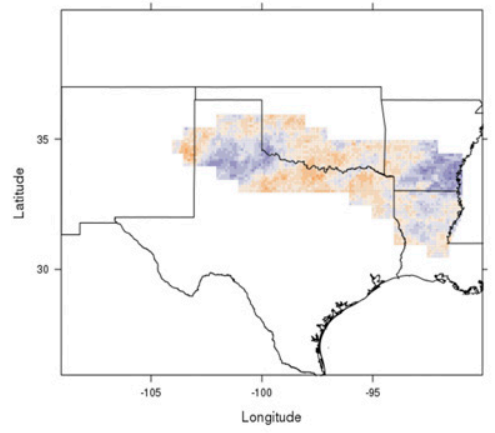

(d) Model: CCSM4, SD: EDQM

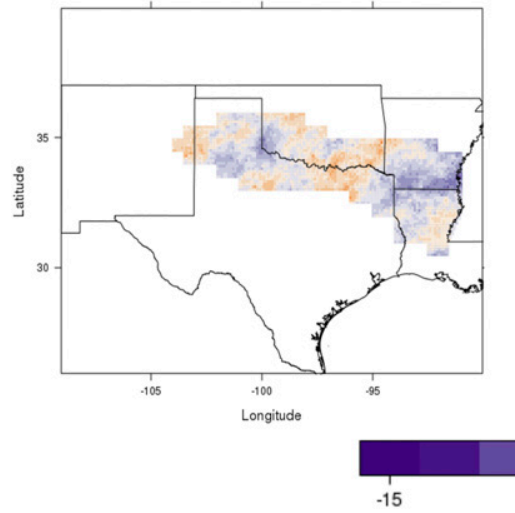

(b) Model: MIROC5, SD: CDFt

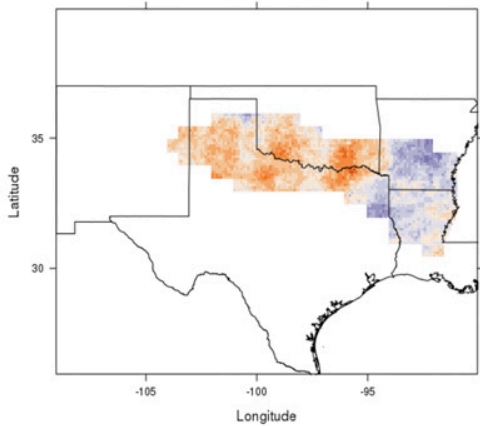

(e) Model: MIROC5, SD: EDQM

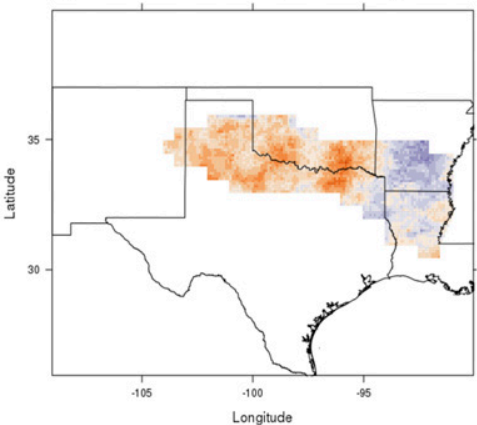

(c) Model: MPI-ESM-LR, SD: CDFt

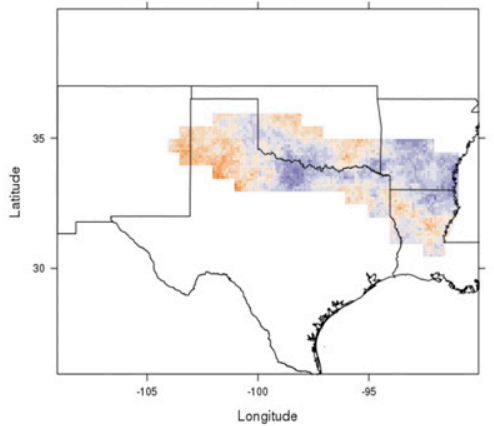

(f) Model: MPI-ESM-LR, SD: EDQM

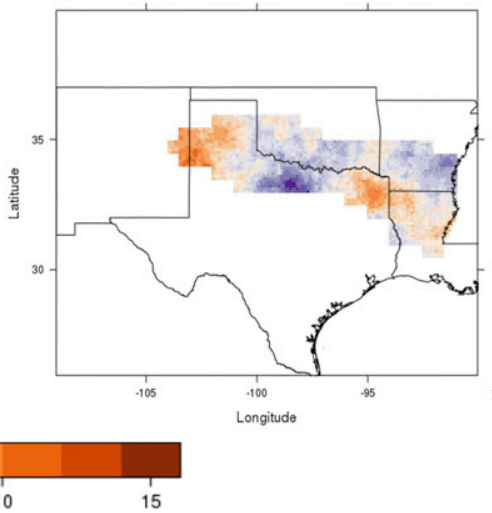

FIG. 9. Change in 25-yr total frequency of severe drought at a 1-month time scale between the historical period (1981-2005) and midcentury period (2046-70) under RCP scenario 2.6. Purple shades represent a decrease in events, and orange shades represent an increase. 
(a) Model: CCSM4, SD: CDFt

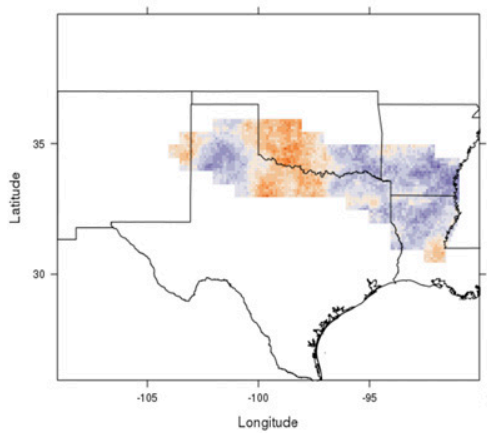

(d) Model: CCSM4, SD: EDQM

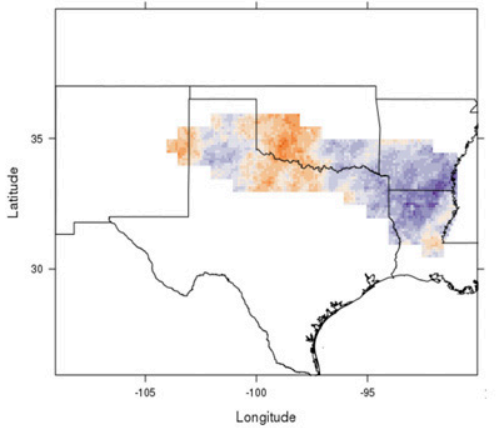

(b) Model: MIROC5, SD: CDFt

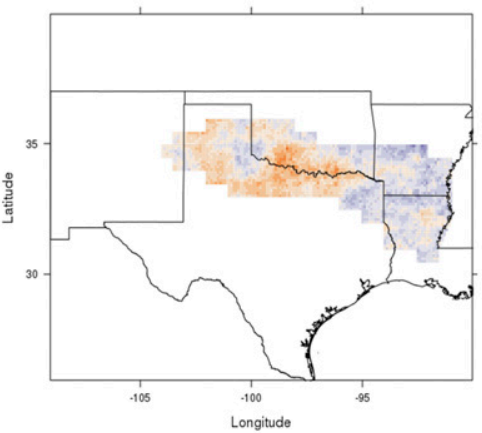

(e) Model: MIROC5, SD: EDQM

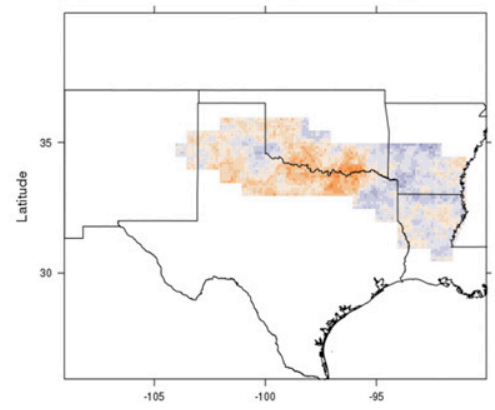

(c) Model: MPI-ESM-LR, SD: CDFt

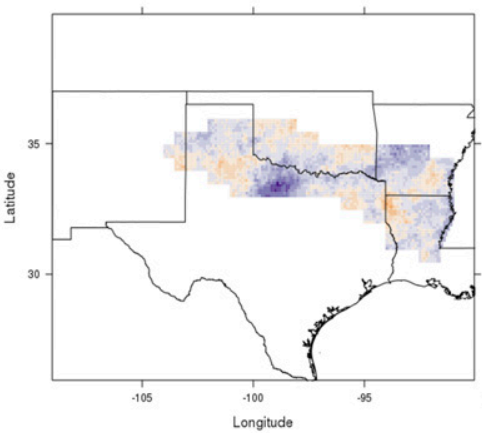

(f) Model: MPI-ESM-LR, SD: EDQM

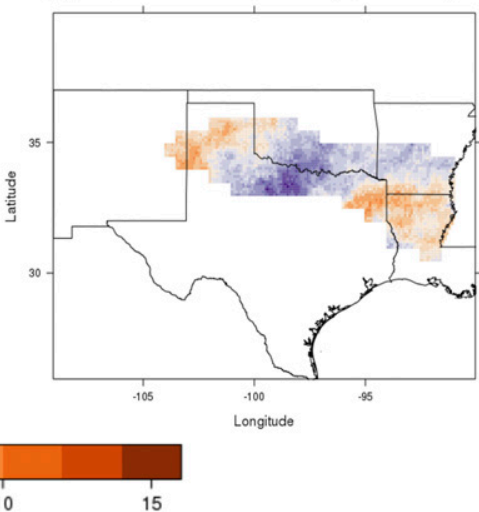

FIG. 10. As in Fig. 9, but between the historical period (1981-2005) and end-of-century period (2075-99) under RCP scenario 8.5.

We detected severe-drought events by using the standardized precipitation evapotranspiration index at a 1-month time scale to depict short-term drought, and values of less than or equal to -1.5 were classified as severe drought. This analysis also included a POT approach to identify the frequency of historical and future severe-drought events. The results from this analysis differed among models, because each model projects precipitation differently. The most common result, although not unanimous among all three models, was an increasing trend in number of severe-drought events in the western Red River basin and a declining trend in the east.

For the eastern basin, a decrease in severe drought would be good news, as drought impacts energy production, water quality and quantity, the ecology of the area, and agriculture. For example, the drought in 2011 led to $\$ 15$ billion in damages in the southern plains (Crouch 2015) and caused a 6\% increase in energy demand and a $30 \%$ reduction in reservoir storage for cooling power plants in Texas (Scanlon et al. 2013). During this event, groundwater levels of aquifers in the region were below normal (Shivers and Andrews 2013). Although this event showcased a longer time scale of drought than our study did, short-term drought can cause impacts to the agricultural and water-resource sectors by a reduction in soil water content and surface flows (Vicente-Serrano et al. 2010a). For the western portion of the basin, an increase in extreme-drought events, coupled with an expected decline in mean precipitation, would create a more dire situation for water resources in this already arid or semiarid region.

Because one of the goals of this study was to aid stakeholders in the region, these results were communicated to stakeholders through a "webinar" that presented the details of the study and what communities may expect in the future with regard to heavy-rainfall and severedrought events. The results of this research will also be displayed on the South Central Climate Adaptation Science Center's Internet site to reach other stakeholders.

There are many factors of uncertainty with our study. First, the time period of the historical observations with which the projections were trained plays a role in the statistics of the downscaled projections. The observation dataset is constrained to the 1961-2005 time period, and our 25-yr selection of 1981-2005 was wetter than other 25-yr periods; therefore, having a longer time series would potentially impact the threshold of the 90th and 
99th percentiles. There is also uncertainty with the GCMs, downscaling techniques, and RCP scenarios. For example, Chen et al. (2011) discussed uncertainty in GCMs and various downscaling techniques and found that GCMs have the largest uncertainty but that the choice of downscaling technique has an impact on results for climate-change studies. Taking these factors into account, we still found common patterns throughout our results, and stakeholders should prepare for all model outcomes. This study aimed to provide information and awareness of the possible scenarios of future hydrologic extremes of the Red River basin and to help stakeholders to understand their future risks so that they can mitigate potential losses.

Acknowledgments. The authors thank the Oklahoma Established Program to Stimulate Competitive Research (EPSCoR) for graciously providing support for the lead author's graduate work, travel, and computing infrastructure. Support for the authors also was provided by the South Central Climate Adaptation Science Center and the Southern Climate Impacts Planning Program. Last, the authors thank Dr. Adrienne Wootten for programming assistance.

\section{REFERENCES}

Amatya, D., R. Skaggs, and J. Gregory, 1995: Comparison of methods for estimating REF-ET. J. Irrig. Drain. Eng., 121, 427435, https://doi.org/10.1061/(ASCE)0733-9437(1995)121:6(427).

Beguería, S., and S. M. Vicente-Serrano, 2013: SPEI: Calculation of the standardised precipitation-evapotranspiration index. $\mathrm{R}$ software package version 1.6, https://CRAN.R-project.org/ package $=$ SPEI.

- - , F. Reig, and B. Latorre, 2014: Standardized precipitation evapotranspiration index (SPEI) revisited: Parameter fitting, evapotranspiration models, tools, datasets and drought monitoring. Int. J. Climatol., 34, 3001-3023, https:// doi.org/10.1002/joc.3887.

Breslin, S., 2015: Southern plains flooding: 31 killed in Texas and Oklahoma; Dry weather finally arrives. The Weather Channel, accessed 17 February 2017, https://weather.com/safety/floods/news/ flash-flooding-heavy-rain-texas-oklahoma-catastrophic-impacts.

Chen, J., F. P. Brissette, and R. Leconte, 2011: Uncertainty of downscaling method in quantifying the impact of climate change on hydrology. J. Hydrol., 401, 190-202, https://doi.org/ 10.1016/j.jhydrol.2011.02.020.

Cheng, L., and A. AghaKouchak, 2014: Nonstationary precipitation intensity-duration- frequency curves for infrastructure design in a changing climate. Sci. Rep., 4, 7093, https://doi.org/10.1038/srep07093.

Contractor, S., L. V. Alexander, M. G. Donat, and N. Herold, 2015: How well do gridded datasets of observed daily precipitation compare over Australia? Adv. Meteor., 2015, 325718, https:// doi.org/10.1155/2015/325718.

Crouch, J., 2015: Reflections on a really big drought. NOAA, accessed 15 March 2016, https://www.climate.gov/news-features/ blogs/beyond-data/reflections-really-big-drought.
Di Liberto, T., 2015: Flood disaster in Texas and Oklahoma. NOAA, accessed 17 February 2017, https://www.climate.gov/newsfeatures/event-tracker/flood-disaster-texas-and-oklahoma.

Dosio, A., 2016: Projections of climate change indices of temperature and precipitation from an ensemble of bias-adjusted high-resolution EURO-CORDEX regional climate models. J. Geophys. Res. Atmos., 121, 5488-5511, https://doi.org/ 10.1002/2015JD024411.

Dracup, J. A., K. S. Lee, and E. G. Paulson, 1980: On the definition of droughts. Water Resour. Res., 16, 297-302, https://doi.org/ 10.1029/WR016i002p00297.

Eden, J. M., M. Widmann, D. Grawe, and S. Rast, 2012: Skill, correction, and downscaling of GCM-simulated precipitation. J. Climate, 25, 3970-3984, https://doi.org/10.1175/ JCLI-D-11-00254.1.

Emori, S., and S. J. Brown, 2005: Dynamic and thermodynamic changes in mean and extreme precipitation under changed climate. Geophys. Res. Lett., 32, L10776, https://doi.org/ 10.1029/2005GL023272.

Ensor, L. A., and S. M. Robeson, 2008: Statistical characteristics of daily precipitation: Comparisons of gridded and point datasets. J. Appl. Meteor. Climatol., 47, 2468-2476, https://doi.org/ 10.1175/2008JAMC1757.1.

Forster, P. M., T. Andrews, P. Good, J. M. Gregory, L. S. Jackson, and M. Zelinka, 2013: Evaluating adjusted forcing and model spread for historical and future scenarios in the CMIP5 generation of climate models. J. Geophys. Res. Atmos., 118, 11391150, https://doi.org/10.1002/jgrd.50174.

Gent, P. R., and Coauthors, 2011: The Community Climate System Model version 4. J. Climate, 24, 4973-4991, https://doi.org/ 10.1175/2011JCLI4083.1.

Giorgetta, M. A., and Coauthors, 2013: Climate and carbon cycle changes from 1850 to 2100 in MPI-ESM simulations for the Coupled Model Intercomparison Project phase 5. J. Adv. Model. Earth Syst., 5, 572-597, https://doi.org/10.1002/jame.20038.

Goswami, B. N., V. Venugopal, D. Sengupta, M. S. Madhusoodanan, and P. K. Xavier, 2006: Increasing trend of extreme rain events over India in a warming environment. Science, 314, 1442-1445, https://doi.org/10.1126/science.1132027.

Guttman, N. B., 1998: Comparing the Palmer drought index and the standardized precipitation index. J. Amer. Water Resour. Assoc., 34, 113-121, https://doi.org/10.1111/j.17521688.1998.tb05964.x.

_ 1999: Accepting the standardized precipitation index: A calculation algorithm. J. Amer. Water Resour. Assoc., 35, 311322, https://doi.org/10.1111/j.1752-1688.1999.tb03592.x.

Gutzler, D. S., and T. O. Robbins, 2011: Climate variability and projected change in the western United States: Regional downscaling and drought statistics. Climate Dyn., 37, 835-849, https://doi.org/10.1007/s00382-010-0838-7.

Hargreaves, G. H., and Z. A. Samani, 1985: Reference crop evapotranspiration from temperature. Appl. Eng. Agric., 1, 96-99, https://doi.org/10.13031/2013.26773.

Hill, C. D., F. Verjee, and C. Barrett, 2010: Flash flood early warning system reference guide. UCAR/NOAA Ref. Guide, 204 pp., http://www.meted.ucar.edu/communities/hazwarnsys/ ffewsrg/FF_EWS.pdf.

IPCC, 2013: What is a GCM? IPCC Data Distribution Centre, accessed 12 July 2016, http://www.ipcc-data.org/guidelines/ pages/gcm_guide.html.

Keyantash, J., and J. A. Dracup, 2002: The quantification of drought: An evaluation of drought indices. Bull. Amer. Meteor. Soc., $\mathbf{8 3}$ 1167-1180, https://doi.org/10.1175/1520-0477-83.8.1167. 
Kharin, V. V., F. Zwiers, X. Zhang, and M. Wehner, 2013: Changes in temperature and precipitation extremes in the CMIP5 ensemble. Climatic Change, 119, 345-357, https:// doi.org/10.1007/s10584-013-0705-8.

Lee, J., 2015: Texas, Oklahoma floodwaters contain sewage, other pollutants. National Geographic, accessed 15 November 2016, http://news.nationalgeographic.com/2015/05/150528-floodwaterchemicals-texas-oklahoma-environment-science-runoff/.

Li, H., J. Sheffield, and E. F. Wood, 2010: Bias correction of monthly precipitation and temperature fields from Intergovernmental Panel on Climate Change AR4 models using equidistant quantile matching. J. Geophys. Res., 115, D10101, https://doi.org/10.1029/2009JD012882.

Liu, B., J. Chen, X. Chen, Y. Lian, and L. Wu, 2013: Uncertainty in determining extreme precipitation thresholds. J. Hydrol., 503, 233-245, https://doi.org/10.1016/j.jhydrol.2013.09.002.

Lockwood, J. G., 1999: Is potential evapotranspiration and its relationship with actual evapotranspiration sensitive to elevated atmospheric $\mathrm{CO}_{2}$ levels? Climatic Change, 41, 193-212, https://doi.org/10.1023/A:1005469416067.

Lu, J., G. Sun, S. G. McNulty, and D. M. Amatya, 2005: A comparison of six potential evapotranspiration methods for regional use in the southeastern United States. J. Amer. Water Resour. Assoc., 41, 621-633, https://doi.org/10.1111/ j.1752-1688.2005.tb03759.x.

Malewitz, J., 2013: Red River showdown: Texas-Oklahoma water war could reverberate across US. Stateline, Pew Charitable Trusts, http://www.pewtrusts.org/en/research-and-analysis/ blogs/stateline/2013/04/24/red-river-showdown-texasoklahomawater-war-could-reverberate-across-us.

Maurer, E. P., and Coauthors, 2014: An enhanced archive facilitating climate impacts and adaptation analysis. Bull. Amer. Meteor. Soc., 95, 1011-1019, https://doi.org/10.1175/ BAMS-D-13-00126.1.

McKee, T. B., N. J. Doesken, and J. Kleist, 1993: The relationship of drought frequency and duration to time scales. Eighth Conf. on Applied Climatology, Anaheim, CA, Amer. Meteor. Soc., 179-184.

Michelangeli, P. A., M. Vrac, and H. Loukos, 2009: Probabilistic downscaling approaches: Application to wind cumulative distribution functions. Geophys. Res. Lett., 36, L11708, https:// doi.org/10.1029/2009GL038401.

National Research Council, 2011: Global Change and Extreme Hydrology: Testing Conventional Wisdom. The National Academies Press, 44 pp., https://doi.org/10.17226/13211.

NOAA, 2016: National Weather Service glossary. NWS, accessed 15 March 2016, http://w1.weather.gov/glossary.

NOAA National Centers for Environmental Information, 2017: Climate at a glance: U.S. time series, Palmer drought severity index (PDSI). Accessed 7 July 2017, https://www.ncdc.noaa.gov/cag/ divisional/time-series/0309/pdsi.

Oklahoma Climatological Survey, 2015: Oklahoma monthly climate summary June 2015. 13 pp., climate.ok.gov/summaries/ monthly/2015/MCS_June_2015.pdf.

_ 2017: Precipitation history: Annual, south central. Accessed 6 July 2017, http://climate.ok.gov/index.php/climate/climate_trends/ precipitation_history_annual_statewide/CD08/prcp/Annual.

Palmer, W. C., 1965: Meteorological drought. Weather Bureau Research Paper 45, 58 pp., https://www.ncdc.noaa.gov/tempand-precip/drought/docs/palmer.pdf.

Prudhomme, C., N. Reynard, and S. Crooks, 2002: Downscaling of global climate models for flood frequency analysis: Where are we now? Hydrol. Processes, 16, 1137-1150, https://doi.org/ 10.1002/hyp.1054.
Scanlon, B. R., I. Duncan, and R. C. Reedy, 2013: Drought and the water-energy nexus in Texas. Environ. Res. Lett., 8, 045033, https://doi.org/10.1088/1748-9326/8/4/045033.

Schmidli, J., C. Frei, and P. L. Vidale, 2006: Downscaling from GCM precipitation: A benchmark for dynamical and statistical downscaling methods. Int. J. Climatol., 26, 679-689, https:// doi.org/10.1002/joc.1287.

Schoof, J. T., and S. M. Robeson, 2016: Projecting changes in regional temperature and precipitation extremes in the United States. Wea. Climate Extremes, 11, 28-40, https://doi.org/ 10.1016/j.wace.2015.09.004.

Shafer, M., D. Ojima, J. M. Antle, D. Kluck, R. A. McPherson, S. Petersen, B. Scanlon, and K. Sherman, 2014: Great Plains. Climate Change Impacts in the United States: The Third National Climate Assessment, J. M. Melillo, T. Richmond, and G. W. Yohe, Eds., U.S. Global Change Research Program, 441-461, http://nca2014.globalchange.gov/report/regions/great-plains.

Sheffield, J., and Coauthors, 2013: North American climate in CMIP5 experiments. Part I: Evaluation of historical simulations of continental and regional climatology. J. Climate, 26, 9209-9245, https://doi.org/10.1175/JCLI-D-12-00592.1.

Shivers, M. J., and W. J. Andrews, 2013: Hydrologic drought of water year 2011 compared to four major drought periods of the 20th century in Oklahoma. U.S. Geological Survey Scientific Investigations Rep. 2013-5018, 52 pp., http://pubs.usgs. gov/sir/2013/5018.

Sillmann, J., V. Kharin, X. Zhang, F. Zwiers, and D. Bronaugh, 2013: Climate extremes indices in the CMIP5 multimodel ensemble: Part 1. Model evaluation in the present climate. J. Geophys. Res. Atmos., 118, 1716-1733, https://doi.org/10.1002/jgrd.50203.

Taylor, J., K. man Lai, M. Davies, D. Clifton, I. Ridley, and P. Biddulph, 2011: Flood management: Prediction of microbial contamination in large-scale floods in urban environments. Environ. Int., 37, 1019-1029, https://doi.org/ 10.1016/j.envint.2011.03.015.

Taylor, K. E., R. J. Stouffer, and G. A. Meehl, 2012: An overview of CMIP5 and the experiment design. Bull. Amer. Meteor. Soc., 93, 485-498, https://doi.org/10.1175/BAMS-D-11-00094.1.

Thornthwaite, C. W., 1948: An approach toward a rational classification of climate. Geogr. Rev., 38, 55-94, https://doi.org/ 10.2307/210739.

Thrasher, B., J. Xiong, W. Wang, F. Melton, A. Michaelis, and R. Nemani, 2013: Downscaled climate projections suitable for resource managers. Eos, Trans. Amer. Geophys. Union, 94, 321-323, https://doi.org/10.1002/2013EO370002.

Tryhorn, L., and A. DeGaetano, 2011: A comparison of techniques for downscaling extreme precipitation over the northeastern United States. Int. J. Climatol., 31, 1975-1989, https://doi.org/ 10.1002/joc.2208.

UCAR, 2011: Climate modeling. Center for Science Education, accessed 10 July 2016, http://scied.ucar.edu/longcontent/ climate-modeling.

USGS, 2017: The national map small scale. Accessed 6 July 2017, https:// nationalmap.gov/small_scale/printable/climatemap.html\#list.

Vavrus, S. J., M. Notaro, and D. J. Lorenz, 2015: Interpreting climate model projections of extreme weather events. Wea. Climate Extremes, 10,10-28, https://doi.org/10.1016/ j.wace.2015.10.005.

Venkataraman, K., S. Tummuri, A. Medina, and J. Perry, 2016: 21st century drought outlook for major climate divisions of Texas based on CMIP5 multimodel ensemble: Implications for water resource management. J. Hydrol., 534, 300-316, https://doi.org/10.1016/j.jhydrol.2016.01.001. 
Vicente-Serrano, S. M., and National Center for Atmospheric Research Staff, Eds., 2015: The climate data guide: Standardized precipitation evapotranspiration index (SPEI). University Corporation for Atmospheric Research, accessed 27 March 2016, https://climatedataguide.ucar.edu/climate-data/ standardized-precipitation-evapotranspiration-index-spei.

- S. Beguería, and J. I. López-Moreno, 2010a: A multiscalar drought index sensitive to global warming: The standardized precipitation evapotranspiration index. J. Climate, 23, 16961718, https://doi.org/10.1175/2009JCLI2909.1.

M. Angulo, and A. El Kenawy, 2010b: A new global $0.5^{\circ}$ gridded dataset (1901-2006) of a multiscalar drought index: Comparison with current drought index datasets based on the Palmer drought severity index. J. Hydrometeor., 11, 1033-1043, https://doi.org/10.1175/2010JHM1224.1.

Villarini, G., J. A. Smith, and G. A. Vecchi, 2013: Changing frequency of heavy rainfall over the central United States. J. Climate, 26, 351-357, https://doi.org/10.1175/JCLI-D-12-00043.1.

Watanabe, M., and Coauthors, 2010: Improved climate simulation by MIROC5: Mean states, variability, and climate sensitivity. J. Climate, 23, 6312-6335, https://doi.org/10.1175/2010JCLI3679.1.

Wilby, R. L., S. P. Charles, E. Zorita, B. Timbal, P. Whetton, and L. O. Mearns, 2004: Guidelines for use of climate scenarios developed from statistical downscaling methods. IPCC Supporting Material, 27 pp., http://www.ipcc-data.org/guidelines/ dgm_no2_v1_09_2004.pdf.
Wilhite, D. A., 2000: Drought as a natural hazard: Concepts and definitions. Drought: A Global Assessment, D. A. Wilhite, Ed., Vol. I, Routledge, 3-18.

- , and M. H. Glantz, 1985: Understanding the drought phenomenon: The role of definitions. Water Int., 10, 111-120, https://doi.org/10.1080/02508068508686328.

Wuebbles, D., and Coauthors, 2014: CMIP5 climate model analyses: Climate extremes in the United States. Bull. Amer. Meteor. Soc., 95, 571-583, https://doi.org/10.1175/ BAMS-D-12-00172.1.

Xue, X., K. Zhang, Y. Hong, J. J. Gourley, W. Kellogg, R. A. McPherson, Z. Wan, and B. N. Austin, 2016: New multisite cascading calibration approach for hydrological models: Case study in the Red River Basin using the VIC model. J. Hydrol. Eng., 21, 05015019, https://doi.org/10.1061/ (ASCE)HE.1943-5584.0001282.

Zhai, P., X. Zhang, H. Wan, and X. Pan, 2005: Trends in total precipitation and frequency of daily precipitation extremes over China. J. Climate, 18, 1096-1108, https://doi.org/10.1175/ JCLI-3318.1.

Zhang, X., L. Alexander, G. C. Hegerl, P. Jones, A. K. Tank, T. C. Peterson, B. Trewin, and F. W. Zwiers, 2011: Indices for monitoring changes in extremes based on daily temperature and precipitation data. Wiley Interdiscip. Rev.: Climate Change, 2, 851-870, https://doi.org/10.1002/ wcc.147. 